University of Nebraska - Lincoln

DigitalCommons@University of Nebraska - Lincoln

Papers in the Earth and Atmospheric Sciences Earth and Atmospheric Sciences, Department

2012

\title{
Nitrogen loss from soil through anaerobic ammonium oxidation coupled to iron reduction
}

\author{
Wendy $\mathrm{H}$. Yang \\ University of California, Berkeley, wendy_yang@berkeley.edu \\ Karrie A. Weber \\ University of Nebraska-Lincoln, kweber@unl.edu \\ Whendee L. Silver \\ University of California, Berkeley, wsilver@berkeley.edu
}

Follow this and additional works at: https://digitalcommons.unl.edu/geosciencefacpub

Part of the Earth Sciences Commons

Yang, Wendy H.; Weber, Karrie A.; and Silver, Whendee L., "Nitrogen loss from soil through anaerobic ammonium oxidation coupled to iron reduction" (2012). Papers in the Earth and Atmospheric Sciences. 372.

https://digitalcommons.unl.edu/geosciencefacpub/372

This Article is brought to you for free and open access by the Earth and Atmospheric Sciences, Department of at DigitalCommons@University of Nebraska - Lincoln. It has been accepted for inclusion in Papers in the Earth and Atmospheric Sciences by an authorized administrator of DigitalCommons@University of Nebraska - Lincoln. 


\title{
Nitrogen loss from soil through anaerobic ammonium oxidation coupled to iron reduction
}

\author{
Wendy H. Yang, ${ }^{1}$ Karrie A.Weber, ${ }^{2}$ and Whendee L. Silver ${ }^{1}$ \\ 1. Department of Environmental Science, Policy, and Management, University of California, Berkeley, California 94720 \\ 2. School of Biological Sciences and Department of Earth and Atmospheric Sciences, University of Nebraska-Lincoln, Lincoln, Nebraska 68588
}

Corresponding author - W. H. Yang, email wendy yang@berkeley.edu

\begin{abstract}
The oxidation of ammonium is a key step in the nitrogen cycle, regulating the production of nitrate, nitrous oxide and dinitrogen. In marine and freshwater ecosystems, anaerobic ammonium oxidation coupled to nitrite reduction, termed anammox, accounts for up to $67 \%$ of dinitrogen production. ${ }^{1-3}$ Dinitrogen production through anaerobic ammonium oxidation has not been observed in terrestrial ecosystems, but the anaerobic oxidation of ammonium to nitrite has been observed in wetland soils under iron-reducing conditions. ${ }^{4,5}$ Here, we incubate tropical upland soil slurries with isotopically labelled ammonium and iron(iii) to assess the potential for anaerobic ammonium oxidation coupled to iron(iii) reduction, otherwise known as Feammox, ${ }^{6}$ in these soils. We show that Feammox can produce dinitrogen, nitrite or nitrate in tropical upland soils. Direct dinitrogen production was the dominant Feammox pathway, short-circuiting the nitrogen cycle and resulting in ecosystem nitrogen losses. Rates were comparable to aerobic nitrification ${ }^{7,8}$ and to denitrification, ${ }^{9}$ the latter being the only other process known to produce dinitrogen in terrestrial ecosystems. We suggest that Feammox could fuel nitrogen losses in ecosystems rich in poorly crystalline iron minerals, with low or fluctuating redox conditions.
\end{abstract}

Terrestrial net primary productivity is often limited by the availability of fixed nitrogen $(\mathrm{N})$ owing in large part to the mobility of $\mathrm{N}$ across ecosystem boundaries, particularly through denitrification. ${ }^{10}$ Denitrification is dominantly a microbial process that converts nitrate $\left(\mathrm{NO}_{3}{ }^{-}\right)$to nitrous oxide $\left(\mathrm{N}_{2} \mathrm{O}\right)$ and dinitrogen $\left(\mathrm{N}_{2}\right)$ gases. In terrestrial ecosystems, denitrification is thought to be the only process by which fixed $\mathrm{N}$ is converted to $\mathrm{N}_{2}$, thereby completing the nitrogen cycle. In aquatic systems, anammox bypasses the potential for $\mathrm{N}_{2} \mathrm{O}$ production as well as decreasing internal $\mathrm{N}$ cycling. Bacteria capable of anammox have been detected in soil, 11,12 but the occurrence of anammox has not been demonstrated in terrestrial ecosystems. ${ }^{13}$

The reduction of ferric iron (Fe(iii)) can be coupled to anaerobic ammonium $\left(\mathrm{NH}_{4}^{+}\right)$oxidation to produce $\mathrm{N}_{2}$ (reference 14), $\mathrm{NO}_{3}{ }^{-}$(reference 14), or $\mathrm{NO}_{2}^{-}$(references 4-6). This process is termed Feammox ${ }^{6}$ and theoretically could occur abiotically or be microbially mediated. There is some evidence of Feammox to $\mathrm{NO}_{2}{ }^{-}$in wetland soils, ${ }^{4}{ }^{5}$ but Feammox to $\mathrm{N}_{2}$ has not been previously described nor has Feammox been measured in upland soils. Feammox to $\mathrm{N}_{2}$ is energetically more favorable than Feammox to $\mathrm{NO}_{2}{ }^{-}$or $\mathrm{NO}_{3}{ }^{-}$and is favorable over a wider range of conditions. Environments rich in poorly crystalline Fe minerals, such as highly weathered soils, have the potential to support Feammox. Under conditions typically found in soil,
Feammox to $\mathrm{N}_{2}$ using ferrihydrite, a common poorly crystalline Fe oxide, yields $-245 \mathrm{~kJ} \mathrm{~mol}^{-1}$ reaction (see Supplementary Equations) through the following process (equation (1)):

$$
3 \mathrm{Fe}(\mathrm{OH})_{3}+5 \mathrm{H}^{+}+\mathrm{NH}_{4}^{+} \rightarrow 3 \mathrm{Fe}^{2+}+9 \mathrm{H}_{2} \mathrm{O}+0.5 \mathrm{~N}_{2}
$$

This reaction remains energetically favorable over a wide $\mathrm{pH}$ range. Feammox to $\mathrm{NO}_{2}{ }^{-}$(equation (2)) occurs only below $\mathrm{pH}$ 6.5 , stoichiometrically requires more $\mathrm{Fe}(\mathrm{iii})$ and yields less energy than Feammox to $\mathrm{N}_{2}\left(-164 \mathrm{~kJ} \mathrm{~mol}^{-1}\right.$ reaction) under the same conditions:

$$
6 \mathrm{Fe}(\mathrm{OH})_{3}+10 \mathrm{H}^{+}+\mathrm{NH}_{4}^{+} \rightarrow 6 \mathrm{Fe}^{2+}+16 \mathrm{H}_{2} \mathrm{O}+\mathrm{NO}_{2}^{-}
$$

Feammox to $\mathrm{NO}_{3}{ }^{-}$is also thermodynamically feasible under these conditions $\left(-207 \mathrm{~kJ} \mathrm{~mol}^{-1}\right.$ reaction).

Feammox rates averaged $1.20 \pm 0.28 \mu \mathrm{g} \mathrm{Ng}^{-1} \mathrm{~d}^{-1}$ ( \pm standard error of the mean) following the addition of both ${ }^{15} \mathrm{NH}_{4}{ }^{+}$and Fe(iii) to a tropical forest soil (Figure 1a). These rates are conservative estimates determined from ${ }^{30} \mathrm{~N}_{2}$ production alone and are comparable to gross aerobic nitrification rates in tropical forests. ${ }^{7,8,15}$ Lower ${ }^{30} \mathrm{~N}_{2}$ production occurred following the addition of ${ }^{15} \mathrm{NH}_{4}^{+}$alone $\left(0.32 \pm 0.13 \mu \mathrm{g} \mathrm{Ng}^{-1} \mathrm{~d}^{-1}, p<0.001\right)$, presumably resulting from the utilization of background $\mathrm{Fe}$ in the Feammox reaction. These soils are rich in poorly crystalline, reactive Fe $\left(6.2 \pm 0.2 \mathrm{mg} \mathrm{Fe}^{-1}\right.$ soil $\left.^{16}\right)$; thus, sufficient background $\mathrm{Fe}$ (iii) was available to drive ${ }^{30} \mathrm{~N}_{2}$ production with the addition of ${ }^{15} \mathrm{NH}_{4}{ }^{+}$alone. At $24 \mathrm{~h}$ after ${ }^{15} \mathrm{NH}_{4}^{+}$addition, $\mathrm{HCl}-$ extractable Fe(iii) concentrations averaged $528 \pm 128 \mu \mathrm{g}$ Fe(iii) $\mathrm{g}^{-1}$. We used replicate $(n=8)$ upland soils $(0-10 \mathrm{~cm}$ depth) from the Luquillo Mountains, Puerto Rico, USA. Soils were slurried and pre-incubated in an anaerobic glove box to remove $\mathrm{O}_{2}$, inhibit aerobic nitrification, and deplete background $\mathrm{NO}_{2}{ }^{-}$and $\mathrm{NO}_{3}{ }^{-}$. Rigorous procedures were used to exclude molecular $\mathrm{O}_{2}$ from the experiment, thereby removing the possibility of aerobic nitrification (see Supplementary Discussion). We then measured ${ }^{30} \mathrm{~N}_{2}\left({ }^{30} \mathrm{~N}_{2}={ }^{15} \mathrm{~N}+{ }^{15} \mathrm{~N}\right)$ and ${ }^{29} \mathrm{~N}_{2}\left({ }^{29} \mathrm{~N}_{2}={ }^{15} \mathrm{~N}\right.$ $+{ }^{14} \mathrm{~N}$ ) mole fractions of headspace gas in samples and soilfree jars (that is, blanks) to determine ${ }^{30} \mathrm{~N}_{2}$ and ${ }^{29} \mathrm{~N}_{2}$ production rates (see Supplementary Methods). Feammox directly to $\mathrm{N}_{2}$ or Feammox-generated $\mathrm{NO}_{2}{ }^{-}$followed by denitrification or anammox are the only possible sources of ${ }^{30} \mathrm{~N}_{2}$ (Table 1). At least two possible mechanisms exist for Feammox: surface $\mathrm{Fe}$ reduction coupled to $\mathrm{NH}_{4}^{+}$oxidation, or $\mathrm{O}_{2}$ liberated from $\mathrm{Fe}$ oxides used for intra-aerobic $\mathrm{NH}_{4}{ }^{+}$oxidation coupled to Fe reduction, similar to anaerobic methane oxidation coupled to $\mathrm{NO}_{2}{ }^{-}$reduction carried out by oxygenic bacteria ${ }^{17}$. 

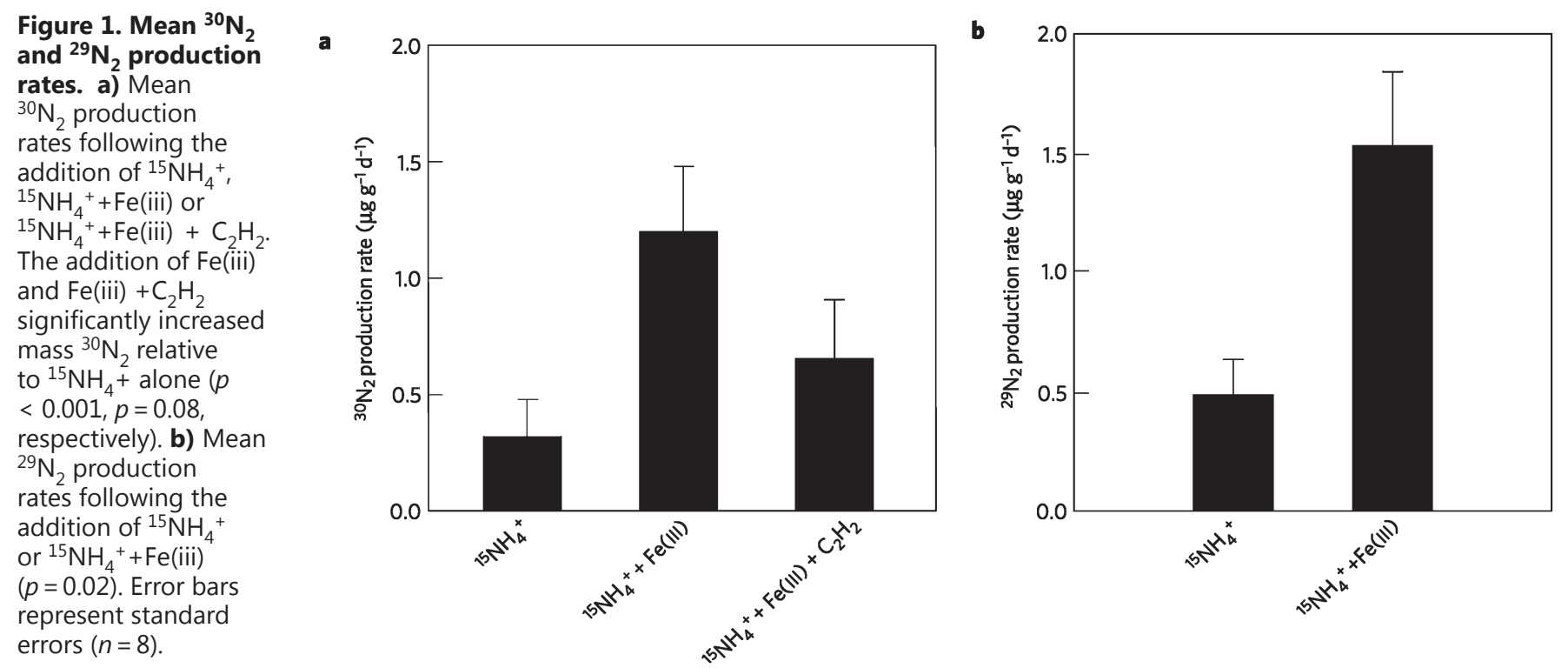

Table 1. Potential pathways for ${ }^{30} \mathrm{~N}_{2}$ and ${ }^{29} \mathrm{~N}_{2}$ production from ${ }^{15} \mathrm{NH}_{4}{ }^{+}$under anoxic conditions.*

\begin{tabular}{|c|c|c|c|}
\hline Product & Nitrogen substrate 1 & Nitrogen substrate 2 & Process \\
\hline${ }^{30} \mathrm{~N}_{2}$ & $\begin{array}{l}\text { Added }{ }^{15} \mathrm{NH}_{4}^{+} \\
\text {Added }{ }^{15} \mathrm{NH}_{4}^{+} \\
\text {Feammox-generated }{ }^{15} \mathrm{NO}_{2}^{-} /{ }^{15} \mathrm{NO}_{3}^{-} \\
\text {Added }{ }^{15} \mathrm{NH}_{4}^{+} \\
\text {Added }{ }^{15} \mathrm{NH}_{4}^{+} \\
\text {Feammox- } \\
\text { Feammox-generated }{ }^{15} \mathrm{NO}_{2}^{-} /{ }^{15} \mathrm{NO}_{3}^{-} \\
\text {Fenated }{ }^{15} \mathrm{NO}_{2}^{-} /{ }^{-15} \mathrm{NO}_{3}^{-}\end{array}$ & $\begin{array}{l}\text { Added }{ }^{15} \mathrm{NH}_{4}^{+} \\
\text {Feammox-generated }{ }^{15} \mathrm{NO}_{2}^{-} / 15 \mathrm{NO}_{3}^{-}{ }^{+} \\
\text {Feammox-generated }{ }^{15} \mathrm{NO}_{2}^{-} / 15 \mathrm{NO}_{3}^{-} \\
\text {Background }{ }^{14} \mathrm{NH}_{4}^{+} \\
\text {Background }{ }^{14} \mathrm{NO}_{2}^{-} /{ }^{14} \mathrm{NO}_{3}^{-} \\
\text {Background }{ }^{14} \mathrm{NH}_{4}^{+} \\
\text {Background }{ }^{14} \mathrm{NO}_{2}^{-} /{ }^{-14} \mathrm{NO}_{3}^{-}\end{array}$ & $\begin{array}{l}\text { Feammox to } \mathrm{N}_{2} \\
\text { Anammox } \\
\text { Denitrification } \\
\text { Feammox to } \mathrm{N}_{2} \\
\text { Anammox } \\
\text { Anammox } \\
\text { Denitrification }\end{array}$ \\
\hline
\end{tabular}

* Dissimilatory $\mathrm{NO}_{3}^{-}$reduction to $\mathrm{NH}_{4}^{+}$cycles background ${ }^{14} \mathrm{NO}_{2}^{-} /{ }^{14} \mathrm{NO}_{3}^{-}$or Feammox-generated ${ }^{15} \mathrm{NO}_{2}{ }^{-} /{ }^{15} \mathrm{NO}_{3}^{-}$to ${ }^{14} \mathrm{NH}_{4}{ }^{+}$or ${ }^{15} \mathrm{NH}_{4}{ }^{+}$, respectively. Thus, it does not create additional pathways for ${ }^{30} \mathrm{~N}_{2}$ and ${ }^{29} \mathrm{~N}_{2}$ production from ${ }^{15} \mathrm{NH}_{4}{ }^{+}$.

+ Feammox can generate ${ }^{15} \mathrm{NO}_{2}^{-}$or ${ }^{15} \mathrm{NO}_{3}^{-}$from added ${ }^{15} \mathrm{NH}_{4}^{+}$

Feammox directly to $\mathrm{N}_{2}$ accounted for $47( \pm 27)$ to $72( \pm 9) \%$ of ${ }^{30} \mathrm{~N}_{2}$ loss in the Fe(iii) and ${ }^{15} \mathrm{NH}_{4}^{+}$treatment (see Supplementary Methods). We used acetylene $\left(\mathrm{C}_{2} \mathrm{H}_{2}\right)$ to separate direct $\mathrm{N}_{2}$ production through Feammox from gaseous $\mathrm{N}$ loss through denitrification of Feammox-generated $\mathrm{NO}_{2}^{-}$and $\mathrm{NO}_{3}^{-}$. Acetylene blocks the reduction of $\mathrm{N}_{2} \mathrm{O}$ to $\mathrm{N}_{2}$ (reference 18), allowing $\mathrm{N}_{2} \mathrm{O}$ produced from denitrification to accumulate in the headspace. The presence of $\mathrm{C}_{2} \mathrm{H}_{2}$ decreased ${ }^{30} \mathrm{~N}_{2}$ production $(p=0.08$; Figure 1a), indicating that $53 \pm 27 \%$ of ${ }^{30} \mathrm{~N}_{2}$ loss resulted from Feammox to $\mathrm{NO}_{2}^{-}$or $\mathrm{NO}_{3}{ }^{-}$. The rate of Feammox to $\mathrm{NO}_{2}^{-}$or $\mathrm{NO}_{3}{ }^{-}$estimated from the difference in ${ }^{30} \mathrm{~N}_{2}$ production with and without $\mathrm{C}_{2} \mathrm{H}_{2}$ addition was $0.59 \pm 0.32 \mu \mathrm{g} \mathrm{Ng}^{-1} \mathrm{~d}^{-1}$. Based on $\mathrm{N}_{2} \mathrm{O}$ production rates in the presence of $\mathrm{C}_{2} \mathrm{H}_{2}$, approximately $0.33 \pm 0.08 \mu \mathrm{g} \mathrm{Ng}^{-1} \mathrm{~d}^{-1}$ was oxidized to $\mathrm{NO}_{2}^{-}$or $\mathrm{NO}_{3}^{-}$and then subsequently reduced to $\mathrm{N}_{2} \mathrm{O}$ through denitrification $\left(28 \pm 9 \%\right.$ of ${ }^{30} \mathrm{~N}_{2}$ production). These two separate estimates suggest that Feammox directly to $\mathrm{N}_{2}$ dominates as the gaseous $\mathrm{N}$ loss pathway.

We also measured significant ${ }^{29} \mathrm{~N}_{2}$ production following the addition of ${ }^{15} \mathrm{NH}_{4}^{+}$alone $(p=0.03)$ and following the addition of $\mathrm{Fe}$ (iii) and ${ }^{15} \mathrm{NH}_{4}^{+}$together $(p<0.001$; Figure $1 \mathrm{~b})$. The production rate of ${ }^{29} \mathrm{~N}_{2}$ was significantly greater following $\mathrm{Fe}$ (iii) and ${ }^{15} \mathrm{NH}_{4}^{+}$addition compared with ${ }^{15} \mathrm{NH}_{4}^{+}$addition alone $(p=0.02)$. Overall, ${ }^{29} \mathrm{~N}_{2}$ accounted for $60 \pm 12 \%$ of the total ${ }^{15} \mathrm{~N}-\mathrm{N}_{2}$ produced, which is consistent with the value of $66 \%$ predicted from random combinations of background ${ }^{14} \mathrm{NH}_{4}{ }^{+}$and added ${ }^{15} \mathrm{NH}_{4}{ }^{+}$. The production of ${ }^{29} \mathrm{~N}_{2}$ is interesting for several reasons. First, the proportion of ${ }^{29} \mathrm{~N}_{2}$ produced suggests that there was not preferential utilization of added ${ }^{15} \mathrm{NH}_{4}^{+}$for $\mathrm{N}_{2}$ production during the experiment, indicating that the ${ }^{14} \mathrm{NH}_{4}^{+}$and ${ }^{15} \mathrm{NH}_{4}^{+}$pools were well mixed. Second, there are several potential sources of ${ }^{29} \mathrm{~N}_{2}$ including Feammox to $\mathrm{NO}_{2}^{-}$followed by anammox to $\mathrm{N}_{2}$, the use of background ${ }^{14} \mathrm{NH}_{4}^{+}$along with added ${ }^{15} \mathrm{NH}_{4}^{+}$in Feammox to $\mathrm{N}_{2}$, or a combination of pathways involving Feammox-generated $\mathrm{NO}_{2}{ }^{-}$or $\mathrm{NO}_{3}{ }^{-}$followed by denitrification (Table 1). All of these pathways, however, require anaerobic $\mathrm{NH}_{4}{ }^{+}$oxidation. Third, the stimulation of ${ }^{29} \mathrm{~N}_{2}$ with $\mathrm{Fe}$ (iii) addition further indicates that Feammox played an important role in anaerobic $\mathrm{NH}_{4}^{+}$oxidation, regardless of the ultimate mechanism for ${ }^{29} \mathrm{~N}_{2}$ generation. Considering the production of both ${ }^{30} \mathrm{~N}_{2}$ and ${ }^{29} \mathrm{~N}_{2}$, anaerobic $\mathrm{NH}_{4}{ }^{+}$oxidation consumed $5-14 \%$ of the added ${ }^{15} \mathrm{NH}_{4}{ }^{+}$label during the experiment.

In a time-series experiment ${ }^{30} \mathrm{~N}_{2}$ production occurred rapidly, within $1.5 \mathrm{~h}$ of adding ${ }^{15} \mathrm{NH}_{4}^{+}$and $\mathrm{Fe}$ (iii) (Figure 2). The change in ${ }^{30} \mathrm{~N}_{2}$ mole fraction over $1.5 \mathrm{~h}$ was equivalent to Feammox rates of $0.48 \pm 0.11 \mu \mathrm{g} \mathrm{Ng}^{-1} \mathrm{~d}^{-1}$. Feammox rates were relatively constant over $9 \mathrm{~h}$ and averaged $0.11 \pm 0.01 \mu \mathrm{g} \mathrm{Ng}^{-1} \mathrm{~d}^{-1}$. These rates were lower than in the previous experiment, probably owing to the higher $\mathrm{pH}$ of the soil $(\mathrm{pH} 5.21 \pm 0.28$ relative to $4.27 \pm 0.02$ ). Theoretically Feammox rates will decrease as $\mathrm{pH}$ increases because the reaction becomes less thermodynamically favorable and the reactivity of Fe oxide minerals decreases as $\mathrm{pH}$ increases. ${ }^{19}$ To test this we conducted a third experiment in tropical forest soils with an initial $\mathrm{pH}$ of $6.12 \pm 0.03$. The rate of ${ }^{30} \mathrm{~N}_{2}$ production following ${ }^{15} \mathrm{NH}_{4}{ }^{+}$and $\mathrm{Fe}(\mathrm{iii})$ addition was 


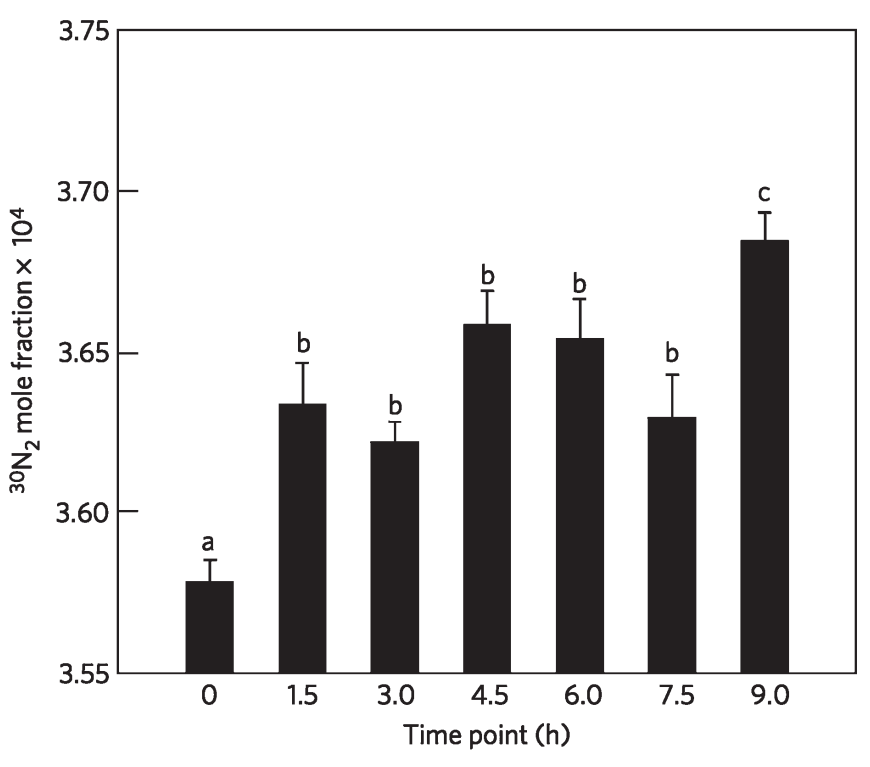

Figure 2. Change in mean ${ }^{30} \mathrm{~N}_{2}$ mole fraction over $9 \mathrm{~h}$. Mean ${ }^{30} \mathrm{~N}_{2}$ mole fraction following the addition of ${ }^{15} \mathrm{NH}_{4}{ }^{+}+\mathrm{Fe}$ (iii) in the time-series experiment. Lowercase letters indicate statistically significant differences among time points using a repeated measures analysis of variance $(p<0.05)$. Bars are mean values $(n=8)$ and standard errors.

considerably lower than under more acidic conditions $(0.02 \pm$ $0.01 \mu \mathrm{g} \mathrm{N} \mathrm{g}^{-1} \mathrm{~d}^{-1}$ during the first $6 \mathrm{~h}$ ) and did not vary significantly at 12 or $25 \mathrm{~h}$ (Figure 3). Iron reduction increased by 115 $\pm 67 \mu \mathrm{g} \mathrm{Fe}(\mathrm{iii}) \mathrm{g}^{-1} \mathrm{~d}^{-1}$ with $\mathrm{NH}_{4}{ }^{+}$and $\mathrm{Fe}(\mathrm{iii})$ addition compared with $\mathrm{NH}_{4}^{+}$addition alone, approximately reflecting the $140 \mu \mathrm{g}$ $\mathrm{Fe}^{-1}$ of Fe(iii) added. This suggests that the added Fe(iii) was readily reducible, although only a small proportion of the Fe(iii) reduced was likely to be associated with $\mathrm{NH}_{4}{ }^{+}$oxidation (see Supplementary Methods).

In a series of calculations, we estimate a potential Feammox rate of $1-4 \mathrm{~kg} \mathrm{NH}{ }_{4}^{+}-\mathrm{Nha}^{-1} \mathrm{y}^{-1}(0-10 \mathrm{~cm}$ depth). Incubations with added substrate may have stimulated Feammox under laboratory conditions and thus we used the theoretical ratios of 3-6 moles of $\mathrm{Fe}(\mathrm{iii})$ reduced per mole of $\mathrm{NH}_{4}^{+}$oxidized based on the thermodynamic calculations instead of measured laboratory rates. Using this approach, only $0.4-0.8 \%$ of Fe reduction is attributable to Feammox. We assumed a mean Fe reduction rate of $25 \mu \mathrm{gFeg}^{-1} \mathrm{~d}^{-1}$ after weighting Fe reduction by the temporal $\mathrm{O}_{2}$ dynamics previously measured at the field site. ${ }^{20}$ This rate of Fe reduction is considerably lower than those measured in the anaerobic slurries, which may have also been stimulated under laboratory conditions (see Supplementary Methods). These results suggest that Feammox is roughly equivalent to total denitrification estimated for this forest. ${ }^{9}$ Similar to denitrification and aerobic nitrification, Feammox is likely to be highly variable in space and time owing to spatial and temporal heterogeneity in substrate availability, redox potential, and $\mathrm{pH}$.

Feammox provides alternative loss pathways of $\mathrm{N}$ from soils, decreasing $\mathrm{N}_{2} \mathrm{O}$ emissions if $\mathrm{NH}_{4}^{+}$is oxidized directly to $\mathrm{N}_{2}$, or potentially increasing $\mathrm{N}_{2} \mathrm{O}$ emissions if Feammox results in $\mathrm{NO}_{2}^{-}$or $\mathrm{NO}_{3}^{-}$followed by incomplete denitrification. However, here we indicate that Feammox to $\mathrm{N}_{2}$ is the dominant gaseous $\mathrm{N}$ loss pathway. Our estimates here have considered Feammox only in the top $10 \mathrm{~cm}$ of soil, but $\mathrm{NH}_{4}^{+}, \mathrm{Fe}(\mathrm{iii})$ and reducing conditions also occur deeper in the soil profile, increasing the importance of this $\mathrm{NH}_{4}^{+}$oxidation pathway.

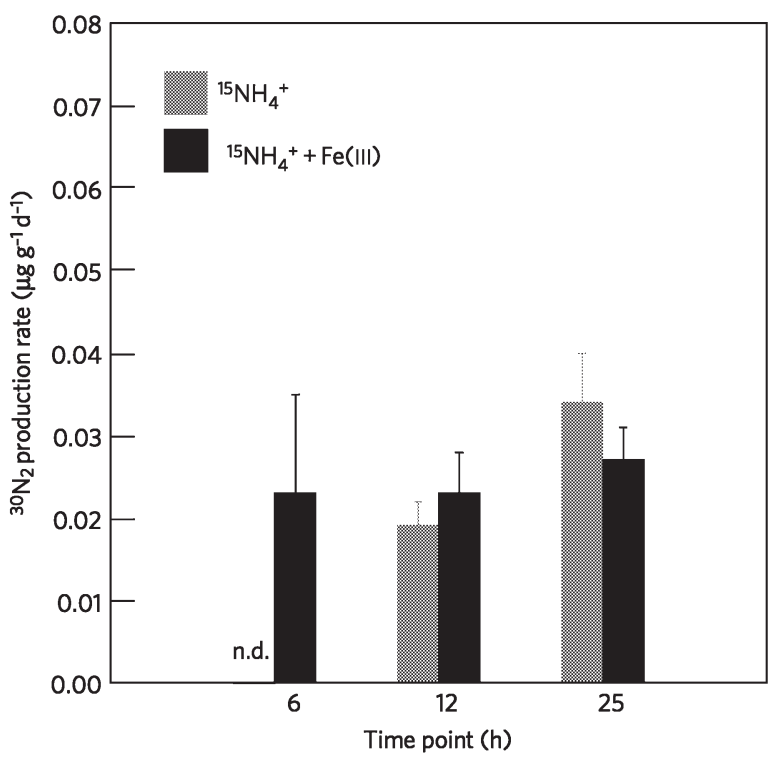

Figure 3: Mean ${ }^{30} \mathrm{~N}_{2}$ production rate at $\mathbf{p H}$ 6. Mean ${ }^{30} \mathrm{~N}_{2}$ production rates following the addition of ${ }^{15} \mathrm{NH}_{4}{ }^{+}$or ${ }^{15} \mathrm{NH}_{4}{ }^{+}+\mathrm{Fe}$ (iii) to tropical forest soils above $\mathrm{pH} 6$. Error bars represent standard errors $(n=8)$. n.d. $=$ not detectable within a detection limit of $0.007 \mu \mathrm{g}^{15} \mathrm{Ng}^{-1} \mathrm{~d}^{-1}$. There was no statistically significant increase in ${ }^{30} \mathrm{~N}_{2}$ production with $\mathrm{Fe}(\mathrm{iii})$ addition.

Feammox is likely to occur in Fe-rich soils that experience periods of anoxia or contain anoxic microsites. Frequent low-redox events have been measured in upland soils in humid regions, during periods of rainfall, or when $\mathrm{O}_{2}$ consumption exceeds diffusive resupply.20-24 Even in well-drained soils, high rates of Fe reduction can occur in well-aggregated clay and organic colloids. ${ }^{25}$ Feammox has not been considered in ecosystem or global models of $\mathrm{N}$ cycling and could change our estimates of total $\mathrm{N}$ losses from terrestrial environments.

\section{Methods}

We slurried surface soil $(0-10 \mathrm{~cm}$ depth) from the Luquillo Experimental Forest. Fresh soil was collected for each experiment on different dates at different locations and was transported to the University of California within $24 \mathrm{~h}$ at ambient temperature in gas-permeable bags. Large roots, leaves, worms and rocks were removed by hand. The fresh soil was then slurried in a 3:1 ratio of milliliters of deionized water (DIW) to grams of soil (oven-dry equivalent). Slurry aliquots, $110 \mathrm{~g}$ each, were divided into $240 \mathrm{ml}$ jars. We also prepared blank jars containing $100 \mathrm{ml}$ DIW. The slurries and blank jars were pre-incubated in the dark in an anaerobic glove box for six days to deplete pre-existing $\mathrm{O}_{2}, \mathrm{NO}_{2}{ }^{-}$, and $\mathrm{NO}_{3}{ }^{-}$. Each experiment was entirely carried out in an anaerobic glove box (Coy Laboratory Products) equipped with palladium catalyst packs to remove $\mathrm{O}_{2}$ and a gas analyzer to monitor $\mathrm{O}_{2}$ concentrations, which remained at $0 \mathrm{ppm}$ throughout the experiments. The glove-box headspace composition was approximately $90 \% \mathrm{~N}_{2}, 8 \%$ carbon dioxide $\left(\mathrm{CO}_{2}\right)$, and $2 \%$ hydrogen.

We carried out a series of three experiments. In the first experiment, we incubated soil with the following treatments to determine if Feammox occurs in soils and to identify the relative importance of the Feammox pathways: ${ }^{15} \mathrm{NH}_{4}{ }^{+}$addition; ${ }^{15} \mathrm{NH}_{4}{ }^{+}$and $\mathrm{Fe}(\mathrm{iii})$ addition; ${ }^{15} \mathrm{NH}_{4}{ }^{+}, \mathrm{Fe}$ (iii), and $\mathrm{C}_{2} \mathrm{H}_{2}$ addition; and soil-free jars (blanks) containing DIW ( $n=8$ per treatment). We sampled the jar headspace gas after $24 \mathrm{~h}$ of incubation. In the second experiment, we determined the timescale at which Feammox occurs after the addition of ${ }^{15} \mathrm{NH}_{4}{ }^{+}$and Fe(iii) $(n=8)$. We sampled headspace gas from the same jars at $1.5 \mathrm{~h}$ intervals up to $9 \mathrm{~h}$ after $\mathrm{NH}_{4}^{+}$and Fe(iii) addition. We calculated ${ }^{30} \mathrm{~N}_{2}$ production rates for each sample from the linear change in ${ }^{30} \mathrm{~N}_{2}$ mole fraction between two given time points. In the third experiment, we measured 
Feammox rates in soil at higher $\mathrm{pH}(\geq 6)$ to determine the effect of $\mathrm{pH}$ on Feammox rates. We incubated soil slurries with the following three treatments: ${ }^{15} \mathrm{NH}_{4}{ }^{+}$addition, ${ }^{15} \mathrm{NH}_{4}{ }^{+}$and $\mathrm{Fe}$ (iii) addition, and soil-free blank jars containing DIW ( $n=8$ per treatment). We sampled the jar headspace gas for determination of ${ }^{30} \mathrm{~N}_{2}$ mole fraction at 6,12 , and $25 \mathrm{~h}$ of incubation. In each experiment we added $6 \mu \mathrm{g} \mathrm{N}-{ }^{15} \mathrm{NH}_{4} \mathrm{Clg}^{-1}$ and sufficient $\mathrm{Fe}$ (iii) to drive Feammox to $\mathrm{NO}_{2}^{-}$using a stoichiometric molar ratio of 6:1 Fe(iii) to ${ }^{15} \mathrm{NH}_{4}{ }^{+}$. The amount of ${ }^{15} \mathrm{NH}_{4}{ }^{+}$added was chosen to increase our ability to detect changes in ${ }^{29} \mathrm{~N}_{2}$ and ${ }^{30} \mathrm{~N}_{2}$ mole fractions while keeping the $\mathrm{NH}_{4}^{+}$pool size at a realistic level. Ammonium pools typically range from 1 to $15 \mu \mathrm{g} \mathrm{Ng}^{-1}$ in this tropical forest and are not correlated with $\mathrm{O}_{2}$ availability. 7, 8, 26

At each sampling time point, each jar was shaken vigorously to equilibrate the $\mathrm{N}_{2}$ between dissolved and gas phases. Duplicate gas samples were taken with gas-tight $500 \mu l$ syringes equipped with zerovolume stopcocks and immediately analyzed for isotopic composition for ${ }^{29} \mathrm{~N}_{2}$ and ${ }^{30} \mathrm{~N}_{2}$ mole fraction. A detailed description of the ${ }^{15} \mathrm{~N}_{2}$ gas analysis technique is given in the Supplementary Methods. A third gas sample $(50 \mathrm{ml})$ was stored for analysis of $\mathrm{N}_{2} \mathrm{O}$ concentration on a Shimadzu GC-14A equipped with an electron capture detector.

After the final gas sampling, the slurries were subsampled for $\mathrm{pH}$ measurement using a $\mathrm{pH}$ electrode (Denver Instruments) and then extracted in $2 \mathrm{M} \mathrm{KCl}$ for colorimetric analysis of $\mathrm{NH}_{4}{ }^{+}$and $\mathrm{NO}_{3}{ }^{-}$using an autoanalyzer (Lachat Quik Chem flow injection analyzer, Lachat Instruments). The extracts were shaken with phosphate and filtered to remove $\mathrm{Fe}$ that could interfere with colorimetric $\mathrm{NO}_{3}{ }^{-}$analysis. ${ }^{27}$ In the third experiment, we also used a $0.5 \mathrm{~N} \mathrm{HCl}$ extraction to determine acid-extractable Fe(ii) concentration. Owing to the high Fe(ii) concentrations in the extracts, we used a modified ferrozine method ${ }^{25}$ to quantify $\mathrm{Fe}(\mathrm{ii})$ concentrations on a Genesys 20 spectrophotometer (ThermoFisher). Iron reduction rates were calculated from the linear change in $\mathrm{Fe}(\mathrm{ii})$ concentrations between sampling time points. All extractions were carried out in the anoxic glove box.

We calculated ${ }^{15} \mathrm{~N}-\mathrm{NH}_{4}{ }^{+}$oxidation rates from the difference in jar headspace ${ }^{29} \mathrm{~N}_{2}$ or ${ }^{30} \mathrm{~N}_{2}$ mole fractions between samples and soil-free blanks (where ${ }^{29} \mathrm{~N}_{2}$ or ${ }^{30} \mathrm{~N}_{2}$ mole fraction $=$ moles of ${ }^{29} \mathrm{~N}_{2}$ or ${ }^{30} \mathrm{~N}_{2}$ divided by moles of total $\mathrm{N}_{2}$ ). To determine ${ }^{15} \mathrm{~N}_{-} \mathrm{NH}_{4}{ }^{+}$oxidation rates from ${ }^{15} \mathrm{~N}_{2}$ production, we used the stoichiometry of the Feammox to $\mathrm{N}_{2}$ pathway. We determined the proportion of Feammox directly to ${ }^{30} \mathrm{~N}_{2}$ as the difference between Feammox to ${ }^{30} \mathrm{~N}_{2}$ and Feammox to $\mathrm{NO}_{2}^{-}$and/or $\mathrm{NO}_{3}^{-}$. A detailed description of the methods is given in the Supplementary Information.

Acknowledgments - We appreciate discussions with M. K. Firestone and field and laboratory assistance from C. Torrens, A. C. McDowell, A. W. Thompson, T. Wood, M. Wong and M. Almaraz. We also thank R. Daly for allowing us to use to her anoxic gas station. This research was supported by grants DEB-0543558, DEB-0842385 and ATM-0628720 to W.L.S., DEB-0841993 to K.A.W., and DDIG 0808383 as well as a Graduate Research Fellowship to W.H.Y. from the US National Science Foundation. Additional support came from NSF grant DEB-0620910 to the Institute of Tropical Ecosystem Studies, University of Puerto Rico, and the International Institute of Tropical Forestry as part of the Long-Term Ecological Research Program in the Luquillo Experimental Forest. The International Institute of Tropical Forestry provided considerable infrastructural and technical support.

Contributions - W.H.Y. and W.L.S. designed the experiments with assistance from K.A.W.; W.H.Y. carried out the experiments with assistance from W.L.S.; W.H.Y. processed the samples and data; W.H.Y. and W.L.S. analyzed the data and wrote the manuscript; K.A.W. carried out the thermodynamic calculations and contributed to the text.

\section{References}

1. Dalsgaard, T. \& Thamdrup, B. Factors controlling anaerobic ammonium oxidation with nitrite in marine sediments. Appl. Environ. Microbiol. 68, 3802-3808 (2002).

2. Kuypers, M. M. M. et al. Massive nitrogen loss from the Benguela upwelling system through anaerobic ammonium oxidation. Proc. Natl Acad. Sci. USA 102, 6478-6483 (2005).
3. Schubert, C. J. et al. Anaerobic ammonium oxidation in a tropical freshwater system (Lake Tanganyika). Environ. Microbiol. 8, 18571863 (2006).

4. Clement, J. C., Shrestha, J., Ehrenfeld, J. G. \& Jaffe, P. R. Ammonium oxidation coupled to dissimilatory reduction of iron under anaerobic conditions in wetland soils. Soil Biol. Biochem. 37, 2323-2328 (2005).

5. Shrestha, J., Rich, J., Ehrenfeld, J. \& Jaffe, P. Oxidation of ammonium to nitrite under iron-reducing conditions in wetland soils: Laboratory, field demonstrations, and push-pull rate determination. Soil Sci. 174, 156-164 (2009).

6. Sawayama, S. Possibility of anoxic ferric ammonium oxidation. J. Biosci. Bioeng. 101, 70-72 (2006).

7. Silver, W. L., Herman, D. J. \& Firestone, M. K. Dissimilatory nitrate reduction to ammonium in upland tropical forest soils. Ecology 82, 2410-2416 (2001).

8. Templer, P., Silver, W. L., Pett-Ridge, J., DeAngelis, D. \& Firestone, M. K. Plant and microbial controls on nitrogen retention and loss in a humid tropical forest. Ecology 89, 3030-3040 (2008).

9. Chestnut, T., Zarin, D., McDowell, W. \& Keller, M. A nitrogen budget for late-successional hillslope tabonuco forest, Puerto Rico. Biogeochemistry 46, 85-108 (1999).

10. Vitousek, P. M. \& Howarth, R. W. Nitrogen limitation on land and in the sea: How can it occur. Biogeochemistry 13, 87-115 (1991).

11. Penton, C., Devol, A. \& Tiedje, J. Molecular evidence for the broad distribution of anaerobic ammonium-oxidizing bacteria in freshwater and marine sediments. Appl. Environ. Microbiol. 72, 68296832 (2006).

12. Humbert, S. et al. Molecular detection of anammox bacteria in terrestrial ecosystems: Distribution and diversity. ISME J. 4, 450-454 (2010).

13. Jetten, M. et al. Biochemistry and molecular biology of anammox bacteria. Crit. Rev. Biochem. Mol. Biol. 4, 65-84 (2009).

14. Luther, G. W., Sundby, B., Lewis, B. L., Brendel, P. J. \& Silverberg, $\mathrm{N}$. Interactions of manganese with the nitrogen cycle: Alternative pathways to dinitrogen. Geochim. Cosmochim. Acta 61, 4043-4052 (1997).

15. Davidson, E. A. et al. Processes regulating soil emissions of NO and $\mathrm{N}_{2} \mathrm{O}$ in a seasonally dry tropical forest. Ecology 74, 130-139 (1993).

16. Dubinsky, E. A., Silver, W. L. \& Firestone, M. K. Tropical forest soil microbial communities couple iron and carbon biogeochemistry. Ecology 91, 2604-2612 (2010).

17. Ettwig, K. F. et al. Nitrite-driven anaerobic methane oxidation by oxygenic bacteria. Nature 464, 543-547 (2010).

18. Yoshinari, T., Hynes, R. \& Knowles, R. Acetylene inhibition of nitrous oxide reduction and measurement of denitrification and nitrogen fixation in soil. Soil Biol. Biochem. 9, 177-183 (1977).

19. Cornell, R. M. \& Schwertmann, U. The Iron Oxides: Structure, Properties, Reactions, Occurrences, and Uses (Wiley, 2003).

20. Liptzin, D., Silver, W. L. \& Detto, M. Temporal dynamics in soil oxygen and greenhouse gases in two humid tropical forests. Ecosystems 14, 171-182 (2011).

21. Sexstone, A. J., Revsbech, N. P., Parkin, T. B. \& Tiedje, J. M. Direct measurement of oxygen profiles and denitrification rates in soil aggregates. Soil Sci. Soc. Am. J. 49, 645-651 (1985).

22. Faulkner, S. P. \& Faulkner, W. H. Redox processes and diagnostic wetland soil indicators in bottomland hardwood forests. Soil Sci. Soc. Am. J. 56, 856-865 (1992).

23. Silver, W. L., Lugo, A. E. \& Keller, M. Soil oxygen availability and biogeochemistry along rainfall and topographic gradients in upland wet tropical forest soils. Biogeochemistry 44, 301-328 (1999).

24. Schuur, E. A. G. \& Matson, P. A. Net primary productivity and nutrient cycling across a mesic to wet precipitation gradient in Hawaiian montane forest. Oecologia 128, 431-442 (2001).

25. Liptzin, D. \& Silver, W. L. Effects of carbon addition on iron reduction and phosphorus availability in a humid tropical forest soil. Soil Biol. Biochem. 41, 1696-1702 (2009).

26. Pett-Ridge, J., Silver, W. L. \& Firestone, M. K. Redox fluctuations frame microbial community impacts on $\mathrm{N}$-cycling rates in a humid tropical forest soil. Biogeochemistry 81, 95-110 (2006).

27. Yang, W. H., Herman, D. J., Liptzin, D. \& Silver, W. L. A new approach for removing iron interference from soil nitrate analysis. Soil Biol. Biochem. 46, 123-128 (2012). 


\title{
Nitrogen loss from soil through anaerobic ammonium oxidation coupled to iron reduction
}

\author{
Wendy H. Yang ${ }^{1}$, Karrie A. Weber ${ }^{2}$, and Whendee L. Silver ${ }^{1}$
}

1. Department of Environmental Science, Policy, and Management, University of California, Berkeley, CA 94720, USA.

2. School of Biological Sciences and School of Earth and Atmospheric Sciences, University of Nebraska-Lincoln. Lincoln, NE, 68588, USA.

\section{Supplementary Information}

\section{Supplementary Methods}

\section{Study Site}

Surface soil (0-10 cm depth) was collected from the Bisley Research Watersheds in the Luquillo Experimental Forest, Puerto Rico. Soils are deep and highly weathered, derived from volcanoclastic material and classified as Ultisols and Oxisols ${ }^{28}$. The climate is relatively aseasonal with a mean annual temperature of $19.1^{\circ} \mathrm{C}$ and a mean annual precipitation of $3500 \mathrm{~mm}^{29-30}$.

\section{Experimental Treatment Additions}

The ${ }^{15} \mathrm{NH}_{4}{ }^{+}, \mathrm{Fe}(\mathrm{III})$, and DI solutions were prepared anoxically ${ }^{31}$, sealed in serum bottles with an anoxic $\mathrm{N}_{2}$ gas headspace, and stored in the glove box before use. The 
Fe(III) was added as hydrous ferric oxide (HFO) synthesized from ferric chloride hexahydrate ${ }^{32}$. Background $\mathrm{NH}_{4}{ }^{+}$concentrations were measured after the pre-incubation period during the first (5.25 $\pm 0.13 \mu \mathrm{g} \mathrm{N} \mathrm{g}{ }^{-1},{ }^{15} \mathrm{NH}_{4}{ }^{+}$enrichment to 54 atom \%) and third experiments $\left(11.05 \pm 0.21 \mu \mathrm{g} \mathrm{N} \mathrm{g}{ }^{-1} ;{ }^{15} \mathrm{NH}_{4}{ }^{+}\right.$pool enrichment to 38 atom \%). In the first experiment, background $\mathrm{NO}_{3}{ }^{-}+\mathrm{NO}_{2}{ }^{-}$concentrations after anoxic pre-incubation averaged $1.30 \pm 0.44 \mu \mathrm{g} \mathrm{N} \mathrm{g}^{-1}$, and in the third experiment, background $\mathrm{NO}_{3}{ }^{-}+\mathrm{NO}_{2}^{-}$ concentrations averaged $0.70 \pm 0.23 \mu \mathrm{g} \mathrm{N} \mathrm{g}^{-1}$. This presence of $\mathrm{NO}_{3}{ }^{-}+\mathrm{NO}_{2}{ }^{-}$after anoxic pre-incubation may be due to background $\mathrm{NO}_{3}{ }^{-}$and/or $\mathrm{NO}_{2}{ }^{-}$production via Feammox.

For the first experiment, the jars were sealed immediately after the treatment solutions were pipetted into the anoxically pre-incubated slurries with custom-made viton gaskets and aluminum lids equipped with $1 / 8$ " Swagelok o-seal fittings and septa for gas sampling. For the second and third experiments, the slurry jars were sealed 24 hours before the treatment solutions were injected into the jars. For all experiments, the jars remained sealed until after the last gas sampling. To begin the incubations, $1 \mathrm{~mL}$ of each treatment solution was added. For the ${ }^{15} \mathrm{NH}_{4}{ }^{+}$only treatment, $1 \mathrm{~mL}$ DI was added in lieu of the $\mathrm{Fe}(\mathrm{III})$ solution. For the $\mathrm{C}_{2} \mathrm{H}_{2}$ treatment, $50 \mathrm{~mL}$ headspace gas was removed and replaced with $50 \mathrm{~mL} \mathrm{C}_{2} \mathrm{H}_{2}$ to achieve $30 \% \mathrm{C}_{2} \mathrm{H}_{2}$ in the headspace. Previous tests showed that lower concentrations of $\mathrm{C}_{2} \mathrm{H}_{2}$ did not completely inhibit $\mathrm{N}_{2} \mathrm{O}$ reduction. The $\mathrm{C}_{2} \mathrm{H}_{2}$ was generated from calcium carbide and de-gassed DI inside of a pre-evacuated vial that had been flushed with helium three times. All jars were shaken vigorously to distribute the treatment solutions and dissolve the $\mathrm{C}_{2} \mathrm{H}_{2}$. 


\section{Gas Analysis}

For the first experiment, $100 \mu \mathrm{L}$ gas samples were immediately analyzed for ${ }^{15} \mathrm{~N}_{2}$ on a PDZ Europa isotope ratio mass spectrometer (IRMS) by direct injection from the gas-tight syringes. The sample was injected upstream of a heated copper reduction tube, Carbosorb trap, and magnesium perchlorate trap to remove $\mathrm{O}_{2}, \mathrm{CO}_{2}$, and water vapor online. For subsequent experiments, $400 \mu \mathrm{L}$ gas samples were analyzed on an IsoPrime 100 IRMS (Elementar, Hanau, Germany) interfaced with a custom-built ${ }^{15} \mathrm{~N}_{2}$ gas analysis system that uses gas chromatography, cryotrapping, and other online gas purification to remove $\mathrm{O}_{2}$, nitric oxide, carbon monoxide, and other gases that can cause interference in measurements of $m / z 28,29$, and 30. Ultra-high purity $\mathrm{N}_{2}$ was used as a standard that was periodically analyzed throughout the day to account for instrument drift. The standard deviation of the references over the course of one day was $10^{-6}$ for the ${ }^{29} \mathrm{~N}_{2}$ mole fraction and $10^{-5}$ for the ${ }^{30} \mathrm{~N}_{2}$ mole fraction on the Europa system and $5 * 10^{-7}$ for the ${ }^{29} \mathrm{~N}_{2}$ mole fraction and $3 * 10^{-6}$ for the ${ }^{30} \mathrm{~N}_{2}$ mole fraction on the IsoPrime system. Stored gas samples were analyzed for $\mathrm{N}_{2} \mathrm{O}$ concentration on a Shimadzu GC-14A equipped with an ECD.

\section{Statistical Analyses}

We performed all statistical analyses using SYSTAT Version 10 (SPSS Inc., Evanston, IL). We log-transformed data as needed to meet the assumptions of student's ttests. We performed two-tailed student's t-tests to compare ${ }^{29} \mathrm{~N}_{2}$ and ${ }^{30} \mathrm{~N}_{2}$ mole fractions between treatments and blanks to determine if significant $\mathrm{NH}_{4}{ }^{+}$oxidation occurred for a 
given treatment. We also compared ${ }^{30} \mathrm{~N}_{2}$ or ${ }^{29} \mathrm{~N}_{2}$ production rates between treatments using two-tailed student's t-tests. We used Gaussian error propagation to estimate errors in rates of Feammox to $\mathrm{NO}_{2}{ }^{-}$or $\mathrm{NO}_{3}{ }^{-}$as well as errors in the percentage of ${ }^{30} \mathrm{~N}_{2}$ loss attributed to direct Feammox to $\mathrm{N}_{2}$.

\section{Calculation of Nitrogen Transformation Rates}

We calculated ${ }^{15} \mathrm{~N}-\mathrm{NH}_{4}{ }^{+}$oxidation rates from the difference in jar headspace ${ }^{29} \mathrm{~N}_{2}$ or ${ }^{30} \mathrm{~N}_{2}$ mole fractions between samples and soil-free blanks (where ${ }^{29} \mathrm{~N}_{2}$ or ${ }^{30} \mathrm{~N}_{2}$ mole fraction $=$ moles of ${ }^{29} \mathrm{~N}_{2}$ or ${ }^{30} \mathrm{~N}_{2}$ divided by moles of total $\mathrm{N}_{2}$ ). We calculated the moles of headspace ${ }^{29} \mathrm{~N}_{2}$ or ${ }^{30} \mathrm{~N}_{2}$ by multiplying the ${ }^{29} \mathrm{~N}_{2}$ or ${ }^{30} \mathrm{~N}_{2}$ mole fractions by the moles of total headspace $\mathrm{N}_{2}$. We determined the moles of total headspace $\mathrm{N}_{2}$ in the jars by using the ideal gas law. The atmospheric pressure was assumed to be $1 \mathrm{~atm}$, and the air temperature was maintained at $24^{\circ} \mathrm{C}$ throughout the experiments. The jar headspace volume was calculated from the empty jar volume $(240 \mathrm{~mL})$ and the weight of the slurry, which was $75 \%$ water (density, $1 \mathrm{~g} \mathrm{~cm}^{-3}$ ) and $25 \%$ dry soil equivalent (bulk density, $\left.0.63 \mathrm{~g} \mathrm{~cm}^{-3[33]}\right)$. The background air in the glove box was approximately $90 \% \mathrm{~N}_{2}$, and we assumed that the $\mathrm{N}_{2}$ concentration did not change detectably during the incubation.

Sensitivity analyses show that a $5 \%$ error in the assumed $\mathrm{N}_{2}$ concentration translates into a $5 \%$ error in the calculated $\mathrm{NH}_{4}{ }^{+}$oxidation rates.

To determine ${ }^{15} \mathrm{~N}-\mathrm{NH}_{4}{ }^{+}$oxidation rates from ${ }^{15} \mathrm{~N}_{2}$ production, we used the stoichiometry of the Feammox to $\mathrm{N}_{2}$ pathway (equation 1), which states that 2 moles of $\mathrm{NH}_{4}{ }^{+}$are required to produce one mole of $\mathrm{N}_{2}$. We accounted for the fact that only one $\mathrm{N}$ 
atom in ${ }^{29} \mathrm{~N}_{2}$ is ${ }^{15} \mathrm{~N}$-labeled whereas both $\mathrm{N}$ atoms in ${ }^{30} \mathrm{~N}_{2}$ are ${ }^{15} \mathrm{~N}$-labeled. The $\mathrm{NH}_{4}{ }^{+}$ oxidation rates were expressed per gram of oven dry soil equivalent in each jar. For our lab experiments, we conservatively report the oxidation of ${ }^{15} \mathrm{NH}_{4}{ }^{+}$as Feammox or anaerobic $\mathrm{NH}_{4}{ }^{+}$oxidation rates rather than scale the ${ }^{15} \mathrm{NH}_{4}{ }^{+}$oxidation rates to the ${ }^{15} \mathrm{~N}$ enrichment of the $\mathrm{NH}_{4}{ }^{+}$pools to obtain total rates that include oxidation of both ${ }^{14} \mathrm{NH}_{4}{ }^{+}$ and ${ }^{15} \mathrm{NH}_{4}^{+}$.

We determined the proportion of Feammox directly to ${ }^{30} \mathrm{~N}_{2}$ as the difference between Feammox to ${ }^{30} \mathrm{~N}_{2}$ and Feammox to $\mathrm{NO}_{2}{ }^{-}$and/or $\mathrm{NO}_{3}{ }^{-}$calculated using the two approaches outlined below. First, we took the difference between measured rates of Feammox to ${ }^{30} \mathrm{~N}_{2}$ without and with $\mathrm{C}_{2} \mathrm{H}_{2}$, which inhibits the reduction of $\mathrm{N}_{2} \mathrm{O}$ to $\mathrm{N}_{2}$. This calculation is based on the assumptions that the $\mathrm{N}_{2} \mathrm{O}$ produced was derived from the ${ }^{15} \mathrm{NO}_{2}{ }^{-}$and/or ${ }^{15} \mathrm{NO}_{3}{ }^{-}$generated by Feammox and that the ${ }^{15} \mathrm{~N}_{2} \mathrm{O}$ was denitrified to ${ }^{30} \mathrm{~N}_{2}$ without $\mathrm{C}_{2} \mathrm{H}_{2}$. The first assumption was supported by the accumulation of $\mathrm{N}_{2} \mathrm{O}$ in the headspace in the presence of $\mathrm{C}_{2} \mathrm{H}_{2}$ and the absence of $\mathrm{O}_{2}$, ruling out aerobic nitrification. The latter assumption was supported by the lack of $\mathrm{N}_{2} \mathrm{O}$ accumulation in the chamber headspace in the absence of $\mathrm{C}_{2} \mathrm{H}_{2}$. For a second, independent approach, we calculated theoretical $\mathrm{NH}_{4}{ }^{+}$oxidation rates from $\mathrm{N}_{2} \mathrm{O}$ production in the presence of $\mathrm{C}_{2} \mathrm{H}_{2}$ (no $\mathrm{N}_{2} \mathrm{O}$ accumulated in the absence of $\mathrm{C}_{2} \mathrm{H}_{2}$ ). Nitrous oxide production rates were calculated using the Henry's law constant to account for production of both gas and dissolved phases of $\mathrm{N}_{2} \mathrm{O}$. We used the stoichiometry of the Feammox to $\mathrm{NO}_{2}{ }^{-}$pathway (equation 2), which states that 1 mole of $\mathrm{NH}_{4}{ }^{+}$is required to produce 1 mole of $\mathrm{NO}_{2}^{-}$. We then assumed that 2 moles of $\mathrm{NO}_{2}^{-}$were required to produce 1 mole of $\mathrm{N}_{2} \mathrm{O}$ via denitrification. 
The high concentration of $\mathrm{C}_{2} \mathrm{H}_{2}$ required to completely inhibit $\mathrm{N}_{2} \mathrm{O}$ reduction (30\%)

precludes ${ }^{15} \mathrm{~N}_{2} \mathrm{O}$ isotopic analysis ${ }^{34}$; thus, this approach could have overestimated Feammox to ${ }^{15} \mathrm{~N}_{2} \mathrm{O}^{-}$or ${ }^{15} \mathrm{NO}_{3}{ }^{-}$by including ${ }^{14} \mathrm{~N}-\mathrm{N}_{2} \mathrm{O}$ production via Feammox.

\section{Calculation of Ecosystem Feammox Rate}

To determine the proportion of Fe reduction that was associated with Feammox, we conservatively used conditions from the ${ }^{15} \mathrm{NH}_{4}{ }^{+}$addition treatment of the third experiment at $\mathrm{pH}$ 6, which exhibited the lowest Feammox rates. The average Fe(III) reduction rate was $232 \pm 50 \mu \mathrm{g} \mathrm{Fe}(\mathrm{III}) \mathrm{g}^{-1} \mathrm{~d}^{-1}$, well within the range reported for humid tropical forest soils (approximately 3-800 ug Fe(III) $\mathrm{g}^{-1} \mathrm{~d}^{-1[16,25,35-38]}$. The percentage of $\mathrm{Fe}(\mathrm{III})$ reduction attributed to Feammox was $0.4 \pm 0.1 \%$ given a theoretical ratio of 3 moles of $\mathrm{Fe}(\mathrm{III})$ reduced per mole of $\mathrm{NH}_{4}{ }^{+}$oxidation to $\mathrm{N}_{2}{ }^{-}$(equation 1 ) or $0.8 \pm 0.2 \%$ given a theoretical ratio of 6 moles of $\mathrm{Fe}(\mathrm{III})$ reduced per mole of $\mathrm{NH}_{4}{ }^{+}$oxidation to $\mathrm{NO}_{2}{ }^{-}$ or $\mathrm{NO}_{3}{ }^{-}$(equation 2) based on thermodynamic calculations.

We weighted $\mathrm{Fe}$ reduction rates by temporal $\mathrm{O}_{2}$ dynamics in the field to better represent the potential periods when Feammox was favorable. We used the frequency distribution of bulk soil $\mathrm{O}_{2}$ concentrations (at $10 \mathrm{~cm}$ depth) previously measured at our study site. Bulk soil $\mathrm{O}_{2}$ concentrations were $<1 \%$ for $20 \%$ of the time and $>1 \%$ for 80 $\%$ of the time ${ }^{21}$. Fe reduction rates previously measured in intact soil from this study site incubated under $21 \% \mathrm{O}_{2}$ averaged $2.7 \mu \mathrm{g} F(\mathrm{III}) \mathrm{g}^{-1} \mathrm{~d}^{-1[28]}$, and we used this value to represent Fe reduction rates under aerobic conditions. Fe reduction rates measured in slurried soils under anoxic conditions for the third Feammox experiment averaged $232 \pm$ 
$50 \mu \mathrm{g} \mathrm{Fe}(\mathrm{III}) \mathrm{g}^{-1} \mathrm{~d}^{-1}$. In a pilot experiment, we observed Fe reduction rates that were twice as high in slurried soils compared to intact soils that were placed in an anoxic glove box for $23 \mathrm{~h}$. We therefore assumed that the Fe reduction rate for intact soil under anoxic conditions was half that for slurried soils, $116 \mu \mathrm{g} F(\mathrm{III}) \mathrm{g}^{-1} \mathrm{~d}^{-1}$. Thus, the overall Fe reduction rate weighted for temporal $\mathrm{O}_{2}$ dynamics was $25 \mu \mathrm{g}$ Fe(III) $\mathrm{g}^{-1} \mathrm{~d}^{-1}$.

If $0.4-0.8 \%$ of Fe reduction $\left(0.1-0.2 \mu \mathrm{g} \mathrm{Fe}(\mathrm{III}) \mathrm{g}^{-1} \mathrm{~d}^{-1}\right)$ in the top $10 \mathrm{~cm}$ of soil is associated with Feammox and soil bulk density is $0.63 \mathrm{~g} \mathrm{~cm}^{-3[33]}$, then on the ecosystem scale, Feammox rates are approximately $1-4 \mathrm{~kg} \mathrm{NH}_{4}{ }^{+}$oxidized $\mathrm{ha}^{-1} \mathrm{y}^{-1}$, comparable to total denitrification estimated for this forest ${ }^{8}$.

\section{Supplementary Discussion}

We took multiple precautions to remove molecular $\mathrm{O}_{2}$ from the soil slurries and thus prevent the contribution of aerobic nitrification to $\mathrm{NH}_{4}{ }^{+}$oxidation. We note that our procedures were similar to or more rigorous than those typically used for quantification of anammox ${ }^{1-3}$. The experiments were performed entirely inside an anaerobic glove box which was maintained at $\mathrm{O}_{2}$ concentrations below $1 \mathrm{ppm}$ (the detection limit of the gas analyzer). In addition, dissolved $\mathrm{O}_{2}$ concentrations in the soil slurries were monitored during the pre-incubation period using a ProODO optical dissolved $\mathrm{O}_{2}$ sensor (YSI, Yellow Springs, $\mathrm{OH}$ ). Dissolved $\mathrm{O}_{2}$ concentrations were below the instrument detection limit of $1 \mu \mathrm{M}$ within 24 hours of pre-incubation. Treatment solutions were prepared anoxically ${ }^{31}$ and accounted for a $2.4 \%$ increase in the water volume of the soil slurries so that negligible $\mathrm{O}_{2}$ was introduced with the treatment solutions. 
Here we outline a calculation to demonstrate that the amount of $\mathrm{O}_{2}$ needed to account for the observed $\mathrm{NH}_{4}{ }^{+}$oxidation rates is much greater than was present given the measurements of glove box headspace $\mathrm{O}_{2}$ concentration as well as dissolved $\mathrm{O}_{2}$ concentrations in the soil slurries. Feammox rates averaged $1.20 \mu \mathrm{g} \mathrm{N} \mathrm{g}^{-1} \mathrm{dry}$ soil d $\mathrm{d}^{-1}$ with $\mathrm{NH}_{4}{ }^{+}$and $\mathrm{Fe}(\mathrm{III})$ addition in soils at $\mathrm{pH}$ 4.2. This is equivalent to $0.4 \mathrm{mg} \mathrm{N}_{-}{ }^{15} \mathrm{NH}_{4}{ }^{+} \mathrm{L}^{-1}$ water $\mathrm{d}^{-1}$ in the soil slurries with a 3:1 gravimetric ratio of water to dry soil. Over a $24 \mathrm{~h}$ incubation, $0.4 \mathrm{mg} \mathrm{N}-{ }^{15} \mathrm{NH}_{4}{ }^{+} \mathrm{L}^{-1}$ or $27 \mu \mathrm{mol} \mathrm{N}-{ }^{15} \mathrm{NH}_{4}{ }^{+} \mathrm{L}^{-1}$ was oxidized. The stoichiometric ratio of $\mathrm{O}_{2}: \mathrm{NH}_{4}{ }^{+}$consumed during aerobic nitrification is $1.5: 1$, and as such, $41 \mu \mathrm{M} \mathrm{O}_{2}$ would be needed to account for the observed $\mathrm{NH}_{4}{ }^{+}$oxidation rates. Dissolved $\mathrm{O}_{2}$ concentrations in the soil slurries were $<1 \mu \mathrm{M}$ within $24 \mathrm{~h}$ of preincubation, and the slurries were pre-incubated for 6 days total with the last day in sealed jars (for the second and third experiments). Thus, there was insufficient $\mathrm{O}_{2}$ present in the jars for aerobic nitrification to account for the measured Feammox rates.

The difference in ${ }^{30} \mathrm{~N}_{2}$ production with and without $\mathrm{C}_{2} \mathrm{H}_{2}$ could be interpreted as reflecting the inhibition of aerobic nitrification. Given the calculation above, $20 \mu \mathrm{M} \mathrm{O}_{2}$ would be required for aerobic nitrification to account for the $0.59 \mu \mathrm{g} \mathrm{N} \mathrm{g}^{-1} \mathrm{dry}_{\text {soil }} \mathrm{d}^{-1}$ difference in ${ }^{30} \mathrm{~N}_{2}$ production rates with and without $\mathrm{C}_{2} \mathrm{H}_{2}$. Thus, the difference in ${ }^{30} \mathrm{~N}_{2}$ production with and without $\mathrm{C}_{2} \mathrm{H}_{2}$ represents only the contribution of Feammox to $\mathrm{NO}_{2}{ }^{-}$ or $\mathrm{NO}_{3}{ }^{-}$to total Feammox rates.

\section{Supplementary Equations}

\section{Calculation of the Thermodynamic Favorability of Feammox Reactions}


The change in Gibbs free energy was calculated to determine thermodynamic favorability of balanced Feammox reactions using the following equation:

$$
\Delta G_{r}=\Delta G_{r}^{\circ}+R T \ln \frac{\{C\}^{c}\{D\}^{d}}{\{A\}^{a}\{B\}^{b}}
$$

Where:

$$
\Delta G_{r}^{\circ}=c \Delta G_{f D}^{\circ}+d \Delta G_{f D}^{\circ}-a \Delta G_{f A}^{\circ}-b \Delta G_{f B}^{\circ}
$$

For the generalized reaction:

$$
a A+b B \rightarrow c C+d D
$$

The energy yield of the balanced redox reaction is denoted as $\Delta G_{r}$, whereas $\Delta G_{r}{ }^{\circ}$ is the sum of the free energy of formation for a chemical species multiplied by the number of moles of each of the products, minus the sum of the free energy of formation multiplied by the number of moles of each reactant. The reaction quotient is the chemical activity of products $(C, D)$ raised to the number of moles of that product $(c, d)$, divided by the activity of reactants $(A, B)$ raised to the number of moles of that reactant $(a, b)$. $R$ is the gas constant which equals $0.008314 \mathrm{~kJ} \mathrm{~mol}^{-1} \mathrm{~K}$, and $\mathrm{T}$ is the absolute temperature in Kelvin $(297.15 \mathrm{~K})$. The chemical activity values used in the calculations are an approximation based on conditions typically found in soils, $\left\{\mathrm{NH}_{4}{ }^{+}\right\}=0.0002 ;\left\{\mathrm{Fe}(\mathrm{OH})_{3}\right\}$ $=1 ;\left\{\mathrm{NO}_{2}^{-}\right\}=0.00001 ;\left\{\mathrm{Fe}^{2+}\right\}=10^{-12}$, at a pH of 5 . An activity of 1 was used for the solid-phase hydrous $\mathrm{Fe}(\mathrm{III})$ oxide minerals, $\mathrm{Fe}(\mathrm{OH})_{3}$, and water (activities of pure solids and liquids are assumed to be equal to unity ${ }^{39}$. Aqueous Fe(III) was not considered as an oxidant in Feammox reactions given that dissolved Fe is not present due to low solubility at a $\mathrm{pH}$ of 5 and above ${ }^{39}$. We also do not show calculations coupling $\mathrm{NH}_{4}{ }^{+}$oxidation to 
the reduction of goethite $(\mathrm{FeOOH})$, a crystalline Fe oxide. Luther and colleagues ${ }^{13}$ reported calculations showing that Feammox to $\mathrm{NO}_{3}{ }^{-}$coupled to goethite reduction is not thermodynamically favorable and that Feammox to $\mathrm{N}_{2}$ coupled to goethite reduction is thermodynamically favorable only below $\mathrm{pH}$ 6.8. Free energies of formation were obtained from Stumm and $\operatorname{Morgan}^{40}: \mathrm{NH}_{4}{ }^{+}, \bar{G}_{f}^{0}=-79.37 \mathrm{~kJ} \mathrm{~mol}^{-1} ; \mathrm{Fe}(\mathrm{OH})_{3}, \bar{G}_{f}^{0}=-699 \mathrm{~kJ}$ $\mathrm{mol}^{-1} ; \mathrm{Fe}^{2+}, \bar{G}_{f}^{\oplus}=-78.87 \mathrm{~kJ} \mathrm{~mol}^{-1} ;$ and $\mathrm{N}_{2}, \bar{G}_{f}^{\oplus}=0 \mathrm{~kJ} \mathrm{~mol}^{-1} ; \mathrm{NO}_{2}^{-}, \bar{G}_{f}^{\varrho}=-37.2 \mathrm{~kJ} \mathrm{~mol}^{-1}$; or $\mathrm{NO}_{3}{ }^{-}, \bar{G}_{f}^{0}=-111.3 \mathrm{~kJ} \mathrm{~mol}^{-1}$.

$$
\begin{aligned}
& 3 \mathrm{Fe}(\mathrm{OH})_{3}+5 \mathrm{H}^{+}+\mathrm{NH}_{4}^{+} \rightarrow 3 \mathrm{Fe}^{2+}+9 \mathrm{H}_{2} \mathrm{O}+0.5 \mathrm{~N}_{2} \quad \text { (Equation 1) } \\
& \Delta G_{r}=\left[3 \Delta G_{f_{F \varepsilon^{2}}}^{\infty}+9 \Delta G_{f_{H_{2} O}}^{\infty}+0.5 \Delta G_{f_{N_{z}}}^{\infty}-3 \Delta G_{f_{F e}(O H)_{s}}^{\infty}-5 \Delta G_{f_{H^{+}}}^{\infty}-1 \Delta G_{f_{N H_{4}^{+}}^{\infty}}^{\infty}\right] \\
& +\left(0.008314 \mathrm{~kJ} \mathrm{~mol}^{-1} \mathrm{~K}\right)(297.15 \mathrm{~K}) \ln \frac{\left\{10^{-12}\right\}^{3}\{1\}^{9}\{0.001\}^{0.5}}{\{1\}^{3}\left\{10^{-5}\right\}^{5}\{0.0002\}^{1}} \\
& \begin{array}{r}
\Delta G_{r}=[3(-78.87)+9(-237.18)+0.5(0)-3(-699)-5(0)-1(-79.37)] \\
+\left(0.008314 \mathrm{~kJ} \mathrm{~mol}^{-1} \mathrm{~K}\right)(297.15 \mathrm{~K}) \ln \frac{\left\{10^{-12}\right\}^{3}\{1\}^{9}\{0.001\}^{0.5}}{\{1\}^{3}\left\{10^{-5}\right\}^{5}\{0.0002\}^{1}}
\end{array}
\end{aligned}
$$$$
\Delta G_{r}=-244.93 \mathrm{~kJ} \mathrm{~mol}^{-1}
$$

$$
\begin{gathered}
6 \mathrm{Fe}(\mathrm{OH})_{3}+10 \mathrm{H}^{+}+\mathrm{NH}_{4}^{+} \rightarrow 6 \mathrm{Fe}^{2+}+16 \mathrm{H}_{2} \mathrm{O}+\mathrm{NO}_{2}^{-} \quad \text { (Equation 2) } \\
\Delta G_{r}=\left[6 \Delta G_{f_{F^{2}}+}^{\infty}+16 \Delta G_{f_{H_{2} O}}^{\infty}+1 \Delta G_{f_{N O_{z}^{-}}^{\infty}}^{\infty}-6 \Delta G_{f_{F e}(O H)_{s}}^{\infty}-10 \Delta G_{f_{H^{+}}}^{\infty}-1 \Delta G_{f_{N H_{4}^{+}}^{\infty}}\right] \\
+\left(0.008314 \mathrm{~kJ} \mathrm{~mol}^{-1} \mathrm{~K}\right)(297.15 \mathrm{~K}) \ln \frac{\left\{10^{-12}\right\}^{6}\{1\}^{16}\{0.00001\}^{1}}{\{1\}^{6}\left\{10^{-5}\right\}^{10}\{0.0002\}^{1}}
\end{gathered}
$$




$$
\begin{aligned}
& \Delta G_{r}=[6(-78.87)+16(-237.18)+1(-37.2)-6(-699)-10(0)-1(-79.37)] \\
& +\left(0.008314 \mathrm{~kJ} \mathrm{~mol}^{-1} \mathrm{~K}\right)(297.15 \mathrm{~K}) \ln \frac{\left\{10^{-12}\right\}^{6}\{1\}^{16}\{0.00001\}^{1}}{\{1\}^{6}\left\{10^{-5}\right\}^{10}\{0.0002\}^{1}} \\
& \Delta G_{r}=-164.48 \mathrm{~kJ} \mathrm{~mol}^{-1} \\
& 8 \mathrm{Fe}(\mathrm{OH})_{3}+14 \mathrm{H}^{+}+\mathrm{NH}_{4}{ }^{+} \rightarrow 8 \mathrm{Fe}^{2+}+21 \mathrm{H}_{2} \mathrm{O}+\mathrm{NO}_{3}^{-} \quad \text { (Equation 3) } \\
& \Delta G_{r}=\left[8 \Delta G_{f_{F \varepsilon^{2+}}}^{\infty}+21 \Delta G_{f_{H_{\mathrm{z}} \mathrm{O}}}^{\infty}+1 \Delta G_{f_{N O_{\mathrm{s}}^{-}}}^{\infty}-8 \Delta G_{f_{\mathrm{F}}(\mathrm{OH})_{\mathrm{g}}}^{\infty}-14 \Delta G_{f_{H^{+}}}^{\infty}-1 \Delta G_{f_{N H_{4}^{+}}}^{\infty}\right] \\
& +\left(0.008314 \mathrm{~kJ} \mathrm{~mol}^{-1} \mathrm{~K}\right)(297.15 \mathrm{~K}) \ln \frac{\left\{10^{-12}\right\}^{8}\{1\}^{21}\{0.00001\}^{1}}{\{1\}^{8}\left\{10^{-5}\right\}^{14}\{0.0002\}^{1}} \\
& \Delta G_{r}=[8(-78.7)+21(-237.18)+1(-111.3)-8(-699)-14(0)-1(-79.37)] \\
& +\left(0.008314 \mathrm{~kJ} \mathrm{~mol}^{-1} \mathrm{~K}\right)(297.15 \mathrm{~K}) \ln \frac{\left\{10^{-12}\right\}^{8}\{1\}^{21}\{0.00001\}^{1}}{\{1\}^{8}\left\{10^{-5}\right\}^{14}\{0.0002\}^{1}} \\
& \Delta G_{r}=-206.97 \mathrm{~kJ} \mathrm{~mol}^{-1}
\end{aligned}
$$

\section{Supplementary References}

28. Soil Survey Staff, “Order 1 Soil Survey of the Luquillo Long-Term Ecological Research Grid, Puerto Rico" (U.S. Department of Agriculture Natural Resources Conservation Service, Washington, DC, 1995).

29. Brown, S. Lugo, A.E., Silander, S. \& Liegal, L. Research history and opportunities in the Luquillo Experimental Forest. USDA Forest Service General Technical Report 44, 1-128 (1983). 
30. Weaver, P.L. \& Murphy, P.G. Forest structure and productivity in Puerto Rico's Luquillo Mountains. Biotropica 22, 69-82 (1990).

31. Hungate, R.E. A roll tube method for cultivation of strict anaerobes. Methods Microbiol. 3B, 117-132 (1969).

32. Lovley, D.R. \& Phillips, E.J.P. Organic matter mineralization with reduction of ferric iron in anaerobic sediments. Appl. Environ. Microbiol. 51, 683-689 (1986).

33. Silver, W., Scatena, F., Johnson, A., Siccama, T. \& Sanchez, M. Nutrient availability in a montane wet tropical forest - spatial patterns and methodological considerations. Plant Soil 164, 129-145 (1994).

34. Malone, J.P., Stevens, R.J. \& Laughlin, R.J. Combining the ${ }^{15} \mathrm{~N}$ and acetylene inhibition techniques to examine the effect of acetylene on denitrification. Soil Biol. Biochem. 30, 31-37 (1998).

35. Peretyazhko, T. \& G. Sposito, G. Iron(III) reduction and phosphorus solubilization in humid tropical forest soils. Geochimica et Cosmochimica Acta 69, 3643-3652 (2005).

36. Chacon, N., Silver, W.L., Dubinsky, E.A. \& Cusack, D.F. Iron reduction and soil phosphorus solubilization in humid tropical forests soils: The roles of labile carbon pools and an electron shuttle compound. Biogeochemistry 78, 67-84 (2006).

37. Thompson, A., Chadwick, O.A., Rancourt, D.G. \& Chorover, J. Iron-oxide crystallinity increases during soil redox oscillations. Geochimica et Cosmochimica Acta 70, 1710-1727 (2006).

38. Teh, Y.A., Dubinsky, E.A., Silver, W.L. \& Carlson, C.M. Suppression of 
methanogenesis by dissimilatory $\mathrm{Fe}(\mathrm{III})$ reducing bacteria in tropical rain forest soils: implications for ecosystem methane flux. Global Change Biology 14, 413-422 (2008).

39. Langmuir, D. Aqueous Environmental Geochemistry 600 (Prentice-Hall, Upper Saddle River, New Jersey, 1997).

40. Stumm, W. \& Morgan, J.J. Aquatic Chemistry: Chemical Equilibria and Rates in Natural Waters (John Wiley, New York, 1996). 